Cheskin, A. (2013) Exploring Russian-speaking identity from below: the case of Latvia. Journal of Baltic Studies . ISSN 0162-9778

Copyright (c) 2012 Journal of Baltic Studies

A copy can be downloaded for personal non-commercial research or study, without prior permission or charge

The content must not be changed in any way or reproduced in any format or medium without the formal permission of the copyright holder(s)

When referring to this work, full bibliographic details must be given

http://eprints.gla.ac.uk/69452/

Deposited on: 6 June 2013

Enlighten - Research publications by members of the University of Glasgow http://eprints.gla.ac.uk 


\title{
EXPLORING RUSSIAN-SPEAKING IDENTITY FROM BELOW: THE CASE OF LATVIA
}

\section{Ammon Cheskin}

\begin{abstract}
Recent research on the acculturation strategies of Russian speakers in Latvia has demonstrated that there is a high level of support for integration (identifying with both Latvian and Russian cultures) compared to marginalization, separation, or assimilation. However, a number of researchers have also highlighted the negative impact of top-down narratives and discourses produced by the country's politicians and journalists. These discourses, it is argued, hamper the integration process by creating incompatible identity positions between 'Russian-speakers' and 'Latvians'. Accordingly, this research turns to focus group interviews with Russian speakers in Latvia in order to uncover the nuances of their identity-forming processes, their relations with the respective Russian and Latvian states, and their acculturation strategies, which are commonly overlooked in top-down accounts. Based on the analysis of the qualitative data it will be argued that there is great potential for an integrated, yet culturally distinct Latvian-Russian identity in Latvia.
\end{abstract}

Keywords: Russian speakers; Latvia; identity; memory; minorities; integration; kin-state relations

Since the collapse of the Soviet Union, 'Russian speakers' in the Baltic states, especially in Latvia and Estonia, have been the subject of a great deal of academic and political attention.

Earlier research on Russian-speaking identity in the Baltic states found there was actually a rather weak sense of collective identity based on the idea of being a Russian speaker (Aasland 1994; Melvin 1995, p. 24). However, in time, the identity of belonging to a community of Russian speakers has become one of the most important identifiers and markers of identity in the Baltic states (Cheskin 2010).

Correspondence to: Ammon Cheskin, University of Glasgow, 8-9 Lilybank Gardens, Glasgow, G12 8RZ, UK. Email: ammoncheskin@yahoo.com 
David Laitin (1995) thus outlined what he saw as the emergence of a 'Russianspeaking nationality' in the Baltic states which was distinct from Russian identity. Indeed, a number of studies have shown that Russian speakers in the Baltic states consider themselves to be very different from Russians in Russia (Vihalemm \& Masso 2003; Zepa 2006). Nevertheless, even with what Melvin (1995) terms the 'Balticization' of Russian speakers in the Baltic states, there are nonetheless clearly visible divisions between popular projections of identity of Russian speakers on the one hand, and the 'core nations' (Estonians/Latvians/Lithuanians) on the other.

For example, studies of media discourse in Latvia (Cheskin 2010; Rožukalne 2010; Sulmane \& Kruks 2001) have revealed a sharp division between the form and content of Latvian-language and Russian-language media. It is often argued (with some justification) that the stereotypes and intolerance of many of the country's media publications help to further demarcate, construct, and propagate the divisions between the two constructed communities and as such have a very real impact on group identities.

In the field of Latvian politics there is also an equally visible and sharp division between 'Latvian' political parties and 'Russian' ones (Golubeva \& Kažoka 2010; Kažoka 2010). In this respect Latvian politics is far more ethnicized than in Estonia, where the majority of Russian speakers with Estonian citizenship tend not to vote for 'Russian' parties but instead most commonly vote for The Estonian Center Party (Eesti Keskerakond; ECP). This leads Solska (2011, p. 1099) to the optimistic conclusion that 'In Estonia, ethnicity is not politicised any more, and economic issues, and recently accession to the Euro-zone, have dominated the public debate and rendered the Estonian political path an unprecedented success story among former Soviet republics'. The comparatively ethnicized nature of Latvian politics has meant that the possibility of an increasingly globalized, or Europeanized, identity based on economic well-being and prosperity proposed by Vihalemm and Masso (2003) and Laitin (2003) is perhaps not as salient in Latvia as it is in Estonia.

In terms of pinning down what differentiates the identities of Russian speakers from Latvians, the theme of historical interpretation has increasingly been seen as a crucial factor. In the analysis of international relations between Russian and Latvia there has been much discussion of the so-called 'memory war' (Mälksoo 2009) between the two sides. Personal and collective memories can be seen as essential elements in the formation of group identities and, for this reason Muižnieks (2011, p. 9) argues that it is impossible to understand Latvian-Russian international relations without an understanding of the role identity plays in forming them.

The Latvian-Russian memory war centers on two distinct interpretations of the history of the Second World War and Latvia's incorporation into the Soviet Union (see Berg \& Ehin 2009; Kattago 2010). From the official Latvian perspective the Soviet Union brutally occupied and tyrannized Latvia through thousands of deportations and also with a targeted and ruthless policy of 'Russification' which involved the relocation of hundreds of thousands of Russian speakers to the republic. From this point of view, Russian speakers and the Russian language are seen as a threat to Latvia's core values, language, and integrity; they are also perceived as remnants of occupation and as disloyal to the Latvian state. In contrast, the Russian perspective emphasizes the heroic role of the Red Army in liberating Latvia from fascism, and 
points a finger at the harsh, uncivilized, and un-European discrimination against Russian speakers in Latvia. This perspective therefore highlights the ostensibly fascistic actions of the Latvian state and individual Latvians against Russian speakers and Russia's great victory over fascism.

However, while these issues of collective memory and historical interpretation have been so effectively explored in studies of Latvian-Russian relations, the literature on the integration and acculturation strategies of Latvia's Russian speakers has thus far preferred to focus more on linguistic proficiency, perceived discrimination, a sense of geographical association with Latvia and Latvian spaces, and contemporary state policies than on the issue of historical interpretation (Pisarenko 2006; Priedite 2005; Zepa et al. 2006, 2008; Laitin 1998; Tabuns 1999).

David Laitin suggested in 1998 that Russian speakers in Latvia and Estonia would gradually choose to assimilate into Latvian and Estonian cultures based on the economically pragmatic expediency of learning the state language and culture. However, recent research has shown that Russian speakers favor integration (identifying with both Latvian culture and Russian culture) over assimilation, marginalization, or separation (Pisarenko 2006). Thus, while approximately 95\% of Russians in Latvia believe that everyone in Latvia should be able to speak Latvian fluently (Zepa et al. 2008, p. 7), Russian speakers have nevertheless been adamant of their right to continue to use Russian in the private and public spheres, and especially in school (see Hogan-Brun 2006).

The fact that a majority of Russian speakers would prefer to maintain their Russian-speaking identity while concurrently integrating into Latvian society and culture is very significant. Linguistically, it is of course possible for an individual to speak both Russian and Latvian fluently. However, when it comes to historical interpretations, commentators are far less optimistic of the chance of any realistic and meaningful integration of two diametrically opposed and 'antagonistic' narratives of the past (Berg \& Ehin 2009).

In order to allow Russian speakers to integrate fully into Latvian society, these conflicting historical narratives must also be integrated. This becomes all the more apparent when we bear in mind that there are particular discourses which have served to secure the actual (re)construction of the Latvian state in the post-Soviet era based on these historical interpretations of Latvia's troubled history. These have included the perpetuation of official historical interpretations, especially of the Second World War, and of subsequent Soviet occupation and trauma (Onken 2007). These also include narratives of a geographical and temporal 'return to Europe' and 'return to normality' (Eglitis 2002), and the belief that 'Latvians' need to be the 'core' and dominant nation in a post-Soviet and independent Latvia (Smith 1999, p. 82).

One result of these discourses has been the emergence of popularized ideals of what it means to be 'Latvian'. This individual, sometimes ironically referred to as 'homo Latviensis' (Zepa 2006, p. 74), must speak Latvian, maintain 'Latvian' cultural values and traits, and display loyalty to the Latvian state by not questioning the state's official narratives and historical interpretations. In many respects this category of citizen can be contrasted with the idealized Soviet individual 'homo Sovieticus' (Peschel 1998, p. 304) and the 'neo-Soviet' narratives which formed the basis of Interfront activities in the perestroika period (Smith et al. 1998, p. 10). It can also be 
contrasted with a person loyal to the ideals and official interpretations of the Russian Federation.

Another visible result of Latvian discourses and narratives can be found in Latvia's much-discussed and controversial citizenship laws (Aasland 2002; Brubaker 1992; Chinn \& Truex 1996), which initially conferred citizenship only on those people who could trace their ancestry to the pre-Soviet Latvia of 1940. This newly (re)constructed citizenry therefore represented Latvia's 'core nation', and was part of the drive to return Latvia to its 'normal' and 'European' self. The vast majority of the group most commonly known today as 'Russian speakers' were ineligible for citizenship as it was thus initially defined. These were people who had mostly arrived in Latvia during the Soviet occupation and were therefore neither 'normal', 'European', nor part of the 'core nation'. As such they became non-citizens until, following pressures from the EU, OSCE, and Council of Europe (Galbreath 2006), Latvia partially relaxed its citizenship laws to allow for a process of naturalization, based on linguistic proficiency in Latvian and a basic knowledge of Latvian history.

Because national identity and a sense of belonging are so closely linked with reciprocal relationships with the state (Croucher 2004), these narratives of Latvian statehood and history can be seen as especially problematic for Russian speakers residing in Latvia. Official state policies have discursively placed them outside the 'core nation'. Nevertheless, the process of 'Balticization' whereby the experience of life in Latvia has led to the development of a particular Baltic, or Latvian, Russian identity has meant that Russian speakers in Latvia are often unable to align their identities fully with the Russian Federation.

Recent research into the actual historical interpretations of the Second World War and Latvia's Soviet history certainly shows a clear division between Russian speakers and ethnic Latvians (Golubeva 2011; Makarov \& Boldāne 2008). Russian speakers are much more likely to agree with Russia's official interpretation that the Baltic states were liberated by the Red Army and that there was no occupation. On the other hand, research has also revealed a tendency for Russian speakers to feel increasingly loyal to Latvia and to Latvian symbols of nationhood (Rodins 2005; Zepa et al. 2005).

Bearing in mind the ostensible desire of Russian speakers to integrate into Latvian society, it was clear that more research was needed in order to explore their discursive strategies more fully, and to investigate how Russian speakers have been able to form their identities in the context of the underlying, official narratives which surround them. Specifically then, this research set out to examine how Russian speakers were, or were not, able to relate to official discourses and narratives propagated by the Latvian Republic, the Russian Federation, and by 'elites' who claim to represent Russian speakers in Latvia. Rogers Brubaker's extensively used triadic nexus famously noted that, in order to understand minority nationalism in postcommunist Central and Eastern Europe, we would need to focus on three elements: "national minorities, the newly nationalizing states in which they live, and the external "homelands" to which they belong' (1996, p. 4).

Research utilizing this nexus has most commonly focused on actual state policies and their impact. This research, however, was designed to examine discursive understandings and placements within this triadic nexus. In their discussion of how 
national identities are discursively constructed, De Cilia, Reisigl, and Wodak (1999, p. 160) propose four categories of macro-strategies which are employed to change or maintain the content and form of national identities: '(1) constructive strategies; (2) perpetuation and justification strategies; (3) transformation strategies; and (4) dismantling or destructive strategies.' These categories are very useful for the study of the discursive origins of national identities in Latvia (see Zepa et al. 2006). However, for the purposes of this study they need to be modified. In the case of Russianspeaking identities, the presence of well-established discourses by the so-called core nation necessitate that we examine the position of Russian speakers specifically in relation to these dominant discourses.

For this reason it is more appropriate to analyze Russian-speaking discourses from the perspective of (1) anti-discourse, (2) integrational discourse and (3) constructive discourse (see Cheskin 2012, p. 329). Anti-discursive positions are those which attempt to dismantle discourses that are seen as undesirable, or incompatible with the identity of the discursive agent. Integrational discourse represents an attempt to fit one's own sense of identity into already established discursive moments. Constructive discourse, rather than directly engaging with previously established discourses, seeks to create new discourses and narratives which can facilitate the individual's identity. By adopting this theoretical framework it is possible to examine contemporary Russian-speaking discourses in relation to elite constructed narratives and discourses.

Focus groups were chosen as an appropriate method with which to employ this methodology and to collect qualitative data from Russian-speaking individuals. The focus groups were conducted in Riga, with the assistance of the Baltic Institute for Social Sciences, and consisted of three groups of participants. The first group $(n=10)$ were aged between 19 and 20 and were all undergraduate students enrolled in various degree courses in Riga. The second group $(n=8)$ were post-graduate students from Riga, aged 22-25. The third and final group $(n=10)$ were aged 40-60 and were all permanent residents of Riga. All participants were native speakers of Russian, where Russian was considered as their first language.

The parameters for these groups were chosen in order to focus primarily on younger, well-educated Russian speakers. Previous research has shown that younger Russian speakers are more likely to possess advanced language skills in Latvian (Zepa et al. 2008), and that language knowledge is positively correlated with a preference for integration (Pisarenko 2006). Russian speakers enrolled in undergraduate and postgraduate courses at a Latvian university would necessarily have to possess a high level of competency in Latvian. In order to understand how Russian speakers were, or were not, able to integrate Latvia's and Russia's official discourses and narratives, it therefore made sense to focus on this group, who would theoretically have a great desire to integrate into Latvian society, and who were already in a linguistic position to do so. The older group of respondents was also chosen in order to contrast the opinions of people who were already adults (aged, as they would have been, between 20 and 40) when the Soviet Union collapsed.

In the course of these focus groups I asked the respondents a number of questions about how they felt in relation to Latvia, Russia, and the Soviet Union, and to various aspects of their identity and sense of belonging. In many respects the questions were 
based on previous research that highlighted the difference in public discourses and beliefs among 'Russian speakers' and 'Latvians' and by people who claim to represent these two constructed groups (Cheskin 2010, 2012; Golubeva 2011; Makarov \& Boldāne 2008; Rožukalne 2010). Often these media discourses present ethnopolitical issues in polemic terms, demarcating 'us' from 'them' and religiously adhering to their 'appropriate' interpretation of history ('Latvian' or 'Russian').

In order to examine how these Russian speakers decoded (Hall 1980) these media and political discourses the participants were also given quotes from, and asked to comment on, articles in a Russian-language newspaper. This research thus presented an opportunity to explore more fully some of the actual positions taken by Latvian Russian speakers on issues which are commonly presented as black and white in the media and political space, and would allow for an examination of how Russian speakers actually did or did not accept public discourses that were aimed at a Russianspeaking audience.

I was interested to note how the respondents of the focus groups reacted to these various discourses and narratives, and how they integrate, or do not integrate, their own sense of identity within, in contradistinction to, or in partial agreement with, discursive understandings that are produced in both the Latvian political and media space, and that of the Russian Federation.

\section{Кто Вы? Who are you?}

The first question posed to all three of the focus groups was how respondents would characterize their nationality (kto vy po natsional'nosti?). Before moving to an analysis of the answers that were given by the respondents, it is important to bear in mind the historical connotations and usage that have been layered within this linguistic sign 'nationality' (Russian natsional'nost', Latvian tautība) in its Latvian context. During the Soviet era, although everyone was a citizen of the USSR, 'nationality' was not defined by one's citizenship. Instead, in every Soviet citizen's passport the individual nationality of the bearer was recorded. The person could choose to record the nationality (sometimes translated into English as ethnicity in this context) of either one of their parents, but could not choose to denote nationality based on residence. Thus, even if a person was a resident in the Soviet Republic of Moldova all their life and felt a genuine attachment to that republic, yet their parents were both 'Russian', then they had no choice but to also be officially classed as Russian.

The complexities of this Soviet categorization of nationality were clearly seen in the responses to my initial question, especially among the older generation of respondents:

You have to understand, it's very complicated. For example, my bloodline (rod) is so mixed up that I can't say what my nationality is. I have Poles in my bloodline, I have Russians. In spirit I'm a Russian insomuch as my language is Russian and I consider myself to be Russian. It's complicated to say what my nationality is. (Respondent aged 40-60) 
Nevertheless, even taking into account the complexities of describing their nationality, the vast majority of respondents in this age group preferred to refer to themselves as Russian:

I'm Russian and very proud of it, although I have various mixed ancestry everywhere. But I consider my identity as Russian. For my child, whose father is $100 \%$ (chistokrovnyi) Ukrainian, we chose Russian nationality. We didn't try to masquerade as this or that. (Respondent aged 40-60)

However, one of the most interesting things about this identification within this age group was that even with such an apparent affinity and attachment to being Russian, there was a near unanimous disapproval of the term 'Russian speaker'. When asked if they approved of the term 'Russian-speaking community' (Russkoyazychnaya ili Russkogovoryashchaya obshchina) only one person indicated that they had no objections to the term. The remainder of respondents in this age group expressed a great deal of unease at the term:

Because it's somehow offensive. Why Russian speakers? Why not Polish speakers or Latvian speakers, why just Russian speakers? (Respondent aged 40-60)

No, please tell me, there's the word 'non-citizen' right? That's the word they thought up for us, and here they thought up 'Russian speakers'.... They invented it that's all! (Respondent aged 40-60)

In the two groups of undergraduate and postgraduate students a small number of respondents expressed a similar complexity of being able to state their nationality. However, there was a lack of any in-depth discussion of family histories, bloodlines, or the different nationalities in the respondents' family trees, as witnessed in the older age group. Instead, the younger participants seemed to be far happier simply to state that they were Russian, with perhaps a fleeting indication that their genealogy was somewhat mixed:

Russian is the generally accepted marker of identity because, in actual fact, most people have mixed blood. (Postgraduate respondent)

Russian, yes. With all sorts of other roots (so vcyakimi pomesyami). (Postgraduate respondent)

What was also significant, from the perspective of this research, was that the younger groups of participants, in contrast to the older age group, did not voice any concerns with the term 'Russian speakers' as a valid signifier. Not one person in either of the undergraduate or postgraduate sample groups stated any problem with this term when asked if they approved of it: "Well, it's our term (laughter)!" (Postgraduate respondent).

This contentment with the term 'Russian speaker' for younger generations of 'Russian speakers' is highly significant. In recent years, the term 'Russian speakers' has been used with increasing frequency by the media and by political elites in Latvia who have invested a lot of effort into creating and strengthening this imagined community (Cheskin 2010). Based on the small sample of my focus groups, there is therefore evidence that this political and journalistic trend has had an influence on the 
way young, non-Latvian, Russian speakers feel about and imagine themselves as a group of people.

However, even though the participants of my focus groups were happy to conceptualize themselves as Russians, or (primarily for the younger respondents) Russian speakers, they also drew a sharp distinction between Russia and Europe, and interestingly placed themselves firmly on the side of Europe:

Here we have the contradistinction of Europe and Russia. This goes for Russians in Estonia and Latvia. We need to view Russians like the Baltic Germans who lived here at the start of the First World War. (Postgraduate respondent)

I was in Pskov, practically on the border with Latvia.... But because Latvia is Europe and Russia isn't Europe, the standard of living naturally differs. (Undergraduate student)

It is interesting that the concept of Europe was used in a fundamentally different way from the way it was used in the Russian-language press. In Latvia's Russian-language press, the concept of Europe is often used as a means to discredit the Latvian state, and to highlight the differences between 'civilized' Europe and 'backwards' Latvia (Cheskin 2010). However, instead of Europe being used as a benchmark with which to judge Latvia's claims to civility and enlightenment, the Russian-speaking respondents in my research used Europe as a positive means to distinguish between Latvia and Russia. In other words, instead of 'Europe' representing an anti-discursive mechanism, here it has an integrational-discursive function.

We should not forget that the discourse of the 'return to Europe' one was one the most salient narratives in Latvia's post-Soviet state (re)building project (Eglitis 2002; Mikkel \& Pridham 2005; Smith et al. 1998). In this respect Russian speakers' conception of 'Europe' found much greater accord with the 'Europe' found within Latvia's narrative of post-Soviet statehood, than with the 'Europe' used by the media.

Indeed, in every instance where the words 'Europe' or 'European' occurred in all three focus group discussions (a total of 41 instances), never was this in connection with a negative, anti-discursive portrayal of Latvia. Instead, it was most commonly linked to an integrational discourse linking Latvia with Europe, and even an 'othering' function of depicting Russia, and Russians in Russia, as non-European and somewhat backwards:

(Respondent 1) I don't know, I think Russia has become outdated.

(Respondent 2) Sovietdom (sovdepiya)! (laughter)

(Respondent 3) Well, it's different there. Europe is Europe. There are European standards and quality products. (Three undergraduate respondents)

The postgraduate group also expressed an understanding that Latvia was far more European than Russia. One postgraduate related how customer service in Russian shops was of a very poor level:

(Respondent 1) You go into a shop and people are very aggressive: 'What do you want?' or 'What are you standing around for?' 
(Respondent 2) Well, here we're closer to the European level, but there it's just Russia - which isn't like anywhere else.

(Respondent 1) Yes and all our good manners come from Europe. (Two postgraduate respondents)

Tentatively, then, we could say that the high frequency of instances of positive geographical alignment between Latvia and Europe points to an increasing integration of Russian-speaking discourse within official Latvian discourse.

\section{The Influence of Russia: Politics, Culture, and Historical Memory-Myths}

One thing we can say for sure, from all of the focus groups, is that Russian speakers generally consider themselves to be fundamentally different from Russians in Russia. In all three of the groups this was a unanimously accepted position:

(Respondent 1) We're completely different; like they say and joke about 'vodka and vobla'. They're so different there...we've somehow become Europeanized.... When you arrive in Moscow everything is different.

(Respondent 2) And they're different.

(Respondent 3)They're different culturally. We're more reserved, not like Russians in terms of temperament - they're more emotional. (Three respondents aged 40-60)

This difference was unequivocally outlined in all three focus groups. Interestingly, alongside the geographical division of Europe-Russia, a number of additional stereotypes were invoked in order to further distance Russians in Russia from Russian speakers in Latvia. In the above example, Respondent 1 makes mention of 'vodka and vobla'. This is a reference to an infamous statement made by ex-Latvian president Vaira Vikse-Freiberga in a 2005 radio interview. Vikse-Freiberga discussed the annual celebrations of the Soviet Army's victory over fascist Germany and the attitudes of a number of Russian-speaking people in Latvia, stating: 'Of course, we won't change the conscience of those old Russians who on May 9 will wrap their vobla in newspaper, drink vodka and sing chastushki while remembering how they heroically conquered the Baltics' (Baltic Times, 2005). ${ }^{1}$ Notwithstanding the conversation being in Latvian, President Vīkse-Freiberga purposefully used the words vobla (dried and salted roach usually drunk with beer), vodka, and chastushki (traditional Russian folk songs) in Russian. However, these stereotypes are here turned around and used in reference to Russians in Russia. Another participant joked that the difference between Russians in Russia and Russians in Latvia was that: 'We don't throw [sunflower] seeds ${ }^{2}$ on the streets and bottles on the Metro (laughter)' (Respondent aged 40-60).

Nevertheless, even with a clear distinction for most respondents between Russians in Russia and Latvian Russians, the abstract concept of Russia still exerts a meaningful and attractive force. When asked what the respondents considered to be their homeland (rodina), they were unanimous in citing Latvia. Then, when asked if 
Russia also represented some form of homeland, the participants agreed that it did. One undergraduate referred to Russia as their 'secondary (vtorostepenyi) homeland', others as their 'spiritual homeland':

As far as the question of [our] relationship with Russia goes, it's a question which in principle has two sides; because in the grand scheme of things there are two Russias. One Russia as a certain, you could say, spiritual homeland primarily because of the Russian language and literature which we've learned at school from a young age - all the writers of Russian literature, and also our parents being from there. And then there's Russia as a modern state - the Russian Federation. I think that the majority of Russians in Latvia don't have any concrete ties with the state, with the Russian Federation, or with the political class. But the ties with Russia as, I don't know, the Russian hockey team, May 9, and so forth are much stronger and much deeper. (Postgraduate respondent, emphasis added)

This distinction between the two Russias, one a political entity, the other a historical, cultural, and symbolic entity, seemed to sum up the general attitude towards Russia. This was underlined by the responses elicited by an excerpt from the Russian-language newspaper Chas (The hour) which was distributed among the participants for discussion. In the article Konstantin Kosachev, the then chairman of Russia's Duma Committee on Foreign Affairs, was quoted as saying:

We should not restrict our campaigning for the Russian world simply to its cultural and historical aspects. It is all good and well if people love Russia, speak Russian, and play Russian folk instruments. But this is not enough.

Does not every diaspora lobby for the interests of its fatherland from the country of its residence? (Chas 2008)

The assertion that Russian speakers in Latvia could be used as some form of lobbying group for the interests of the Russian Federation was generally met with a mix of amusement and derision:

It's incredible that such an educated person can say such funny things. (Respondent aged 40-60)

In all honesty I probably consider myself a Latvian (latviika) .... Yes, Russia is my historical homeland, but I have never been there, and if the truth be told I'm not going to fight for them. (Undergraduate respondent)

Nevertheless, in the same Chas article Mr. Kosachev refers to the 'Russian world', which for him clearly includes Latvia. Asked whether the respondents were in fact living in this so-called Russian world the answer came back that, yes, indeed they did inhabit such a space: 'It's our world, the world of Russians in Latvia' (Respondent aged 40-60).

Again, however, the distinction was clearly drawn between the cultural Russian world and the political Russian world: 'The Russian world (russkii mir), but not the world of the Russian Federation (rossiiskii mir)' (Postgraduate respondent).

In light of these comments there is a certain ambiguity as to the potential impact of Russia on the identity formation of Russian speakers in Latvia. Politically the 
responses of the focus group participants point to a negligible potential for the Russian Federation to have any meaningful impact on Latvian Russian speakers. However, culturally there is an obvious link between the 'historical homeland' of Russia and the world inhabited by contemporary Russian speakers in Latvia.

For example, one of the main areas of concern for the Russian Federation with respect to its foreign policy has been a desire to strengthen its historical interpretation of the Second World War (Foreign Policy Concept of the Russian Federation 2008). In the Baltic context, as has been stated, there is often a sharp divide in the interpretations of the Second World War proffered by the Baltic states and by the Russian Federation.

With these historical complexities and antagonisms in mind I was interested to see how the participants would respond to the question of Soviet occupation. In truth there was a wide range of responses in answer to whether it was fair to talk of Soviet occupation in the Baltic states. Some expressed a straightforward acceptance of the occupation, i.e. full integration within the Latvian discourses of historical interpretation: 'It's a political game. There was an occupation. What, in 1940 did someone invite [the Soviets] in? That's all nonsense' (Respondent aged 40-60).

Others were more inclined to defend the actions of the Soviet Union:

Latvians think that the Russians should have liberated this country and then just left. In reality, if we think about it logically, what would have happened if the Germans had remained here all this time? They would have set up concentration camps and killed the Latvians in these camps. After all that it's just funny to hear that the Latvians aren't happy. (Undergraduate respondent)

On the other hand, a number of people also adopted a fairly noncommittal stance towards the question of occupation, perhaps seeing it as an issue that should simply be put to rest:

There are always two sides to anything and so there's never one opinion. That's why people are never satisfied ... and why it's completely senseless. In Latvia it's easier to keep quiet than to prove your point of view, or to prove that you're right. (Undergraduate respondent)

Generally, however, even if the concrete question of whether or not there was a Soviet occupation was seen primarily as a 'problem of terminology' (postgraduate student), the respondents were far more eager to point out that the Soviet Union was not an entirely negative phenomenon for Latvia. Examples were given of factories that used to operate in Soviet times which have since been closed, and of a life that was, in many respects, better than at present.

The question of the occupation then was treated on two levels. On one level, there was the academic question of a correct legal and moral definition for the events of World War II. On another level there was a discussion of the ways in which the acceptance of occupation was manipulated by certain political forces:

If we just look at the terminology [of the word occupation] then I'm completely tolerant of it and think it's fine. But for Latvians, occupation is a real kind of hurt. 
Well, at the moment, I don't know, I think that now they only talk about it to turn Latvians against Russians. There's even the Museum of Occupation which is next to here. (Two undergraduate respondents)

Thus, even in the above example, when the Museum of Occupation was mentioned in connection with the desire to turn Latvians against Russians, the respondent, when asked whether they objected to the museum, stated that they did not. It would seem, therefore, that the respondents were wary of the Latvian discourse of occupation, which is so observable in media and political discourse (Rožukalne 2010). According to the official discourse, as implemented in the country's official policies on citizenship, and enshrined in, among other things, the Museum of the Occupation, the majority of Russian speakers are a direct consequence of occupation. ${ }^{4}$ Therefore, for a majority of Russian speakers, to admit to occupation is to admit to being an occupier:

Well, it's not nice to be occupiers of course, but you get used to it. (Respondent aged 40-60)

Latvians are always saying, and I hear it, 'Russian occupiers (Krievu okupanti)', and so on. (Undergraduate respondent)

In terms of placing themselves neatly within the official discourses of the Russian Federation or of Latvia, Russian speakers are thus in a difficult position. If they were to adopt a fully integrational discursive approach to the question of occupation then it would only serve to alienate them further from the Latvian state and push them 'back' toward Russia - it would be tantamount to admitting that they have no morally or legally justified place in modern Latvia. On the other hand, as we have seen, the attraction of the Russian Federation is actually rather weak, even if the more abstract attraction of 'cultural Russia' is relatively strong.

Nevertheless, notwithstanding this tension, we can generally surmise that the official discourse of Russia, vis-à-vis its historical interpretation of the Second World War, is largely supported by Russian speakers in Latvia. In many ways the memorymyths of the war have been passed down from parents and grandparents to the younger generations of Russian speakers. For this reason the respondents related the great importance they attached to 9 May. A number of people noted that their parents or grandparents had participated in the war and that they had a duty to pay their respects for the sacrifices that were made for them. The discursive bonds of family should not be underestimated here. For Russian speakers to integrate into the official Latvian discourse of occupation would necessarily entail admitting that the heroic achievements of their parents and grandparents were perhaps not as heroic as some have suggested:

My great-grandfather and great-grandmother, who are now in heaven, lived through the war. And my grandmother and grandfather both were alive at the time of the war. People lived and [9 May] is about remembering. They liberated us from fascism. They aren't occupiers but liberators! (Postgraduate respondent)

One has only to tune into Russian (rossiiskii) television for a few days to see how Red Army veterans from the Second World War are treated with the utmost 
reverence, or to note the sheer number of broadcasts devoted to the theme of the Great Patriotic War, including countless documentaries and feature-length films. It thus seems 'natural' that Russian speakers would not wish to defile the sacred memory of their relatives by debasing their heroic achievements. For this reason, a number of subsequent positions are also maintained. As noted above, a number of respondents pointed to the positive achievements of the Soviet Union in Latvia, not least of course saving the country from the despotism of fascism, but also its positive achievements in Latvia's social and economic development:

Yes, in principle, almost all of what was built in Latvia was built when the Russians were here, when we had the Soviet Union. But they still whine about it today (laughter). (Undergraduate respondent)

As Duncan Bell argues (2008, p. 150), memory is a very different thing from myth: memories are events which are personally experienced; myths are the necessarily simplified and recontextualized transmission of memories to others. In the context of Russian speakers in Latvia, the memory of the Second World War has been (mostly) buried with the parents and grandparents of today's Russian speakers. In its place we now have a generally accepted collective myth of the war. This myth, instead of representing a view from one point in time, contextualizes and justifies the actions of a particular time within the understanding of postwar history. Thus, the myth of the Second World War would seem to be an extremely important nodal point in the suturing of Russian-speaking/Russian identity not only in Russia, but also in Latvia.

To this end, the importance of the Russian Federation is significant in the maintaining of such memory myths. Nevertheless, this is not to say that there was not an observable influence also from the Latvian state and from various Latvian sources.

\section{The Influence of Latvia: Integrational or Anti-Discourse?}

The data gathered from my focus groups reveal a complex relationship between Russian speakers and the Latvian state. In both instances there were occurrences of anti- and integrational discourse in relation to Latvian state discourses and narratives. To deal with the complex issue of the relationship between Russian speakers and the Latvian state I will firstly outline the ways in which Russian speakers employed integrational discourse within the focus groups, followed by an examination of instances of anti-discourse.

In my previous media analysis of Latvian newspaper discourse (Cheskin 2010) I found a great deal of integrational discourse whereby Russian speakers were linked to historically established Latvian discursive relations. In the course of the focus groups that I conducted there was also a high frequency of Russian speakers integrating into Latvian discursive understandings. On the topic of 9 May, as we have seen, although generally the respondents adhered to the standard official interpretation of historical events of the Russian Federation, there were nonetheless a few participants who were happy to say there was an occupation. 
Added to this, there were indications that the respondents were generally aware that the history of the Second World War was perhaps not as straightforward as it was often presented in either the Russian or Latvian official versions.

This was evident in our discussions of the 16 March marches in remembrance of the Latvian Waffen SS legionnaires which occur annually in the Latvian capital Riga. Even though, in many respects, the 16 March parades present the polar opposite perspective on Latvia's experiences in World War II, the focus group participants did not condemn those who participated but rather acknowledged that history was complicated:

(Respondent 1) It's actually complicated. Everyone has their own truth.

(Respondent 2) It's their right [to march]. We can't condemn these old men who participate. They were alive back then.

(Respondent 1) They have their rights, they see things in their own way. They were on the other side. It's really complicated when we judge them on various grounds. But those people have it stuck in their minds. They were on the other side, and they see things completely differently.

(Respondent 3) We can't condemn them. (Three postgraduate respondents)

There were also many other instances where the Russian-speaking participants of my focus groups expressed opinions which could be categorized as integrational discourse. Firstly, there was a deep affection for Latvia as a beautiful and good place to live: 'Well, personally I like it in Latvia; it's a beautiful place Riga, and Latvia' (Undergraduate respondent).

Moreover, in response to the question 'Do you identify more with Russia or Latvia?' every single participant responded that they identified more with Latvia:

[I identify more] with Latvia most likely. Russia is somehow far away and there are so many people there that you don't have any real place. But in Latvia you feel needed. (Postgraduate respondent)

Added to this there was not a single instance of any respondent in any of the three groups who expressed a negative opinion towards Latvian culture or towards the Latvian language in and of itself. Instead there was a widely accepted belief that everyone in Latvia should learn Latvian, and should also respect Latvian culture.

This is an extremely beautiful country and without the Latvian language it wouldn't be Latvia. And I would have thought that, in principle, most people sitting here also wouldn't want Latvian to disappear. (Undergraduate student)

The state language is Latvian and we should know Latvian. (Respondent aged 40-60)

One of the main state mechanisms that has been utilized in order to secure the status of the Latvian language has been Latvia's education reforms which came into force in 2004 and required all 'Russian' schools to move to a bilingual system of education with at least $60 \%$ of the curriculum being taught in Latvian (see HoganBrun 2006). A very interesting point that emerged from the focus groups was that, 
contrary to my personal expectations, the respondents did not condemn the 2004 education reforms which affected Russian-speaking schools. It should be remembered that the respondents from both the undergraduate and postgraduate group would have been pupils in 2003-2004 during the furor surrounding the education reforms indeed, many of them recalled attending protests against the reforms. However, when questioned about their views on the reforms, most people were actually rather stoic about their effects, and even viewed them positively:

When the reforms happened, it was mostly secondary school pupils who were affected by them; people who in many schools hadn't been learning Latvian from an early age .... But now people learn Latvian from the first year of school, and even from pre-school. So here there's practically no problem for the majority because from childhood they know Latvian. (Postgraduate respondent)

It's good like it is now. Even if we've been coerced then at least we've been coerced. And if I know Latvian then it's thanks to this coercion which is set out by this law. (Undergraduate respondent)

However, before getting carried away with the extent of Russian speakers' identification with Latvia, Latvian culture, and Latvian language, we should also consider the numerous instances where Russian speakers have had great difficulty integrating into Latvian discourse. In the Russian-language press Russian speakers are often depicted as highly discriminated against and journalists spend a great deal of time highlighting just how marginalized Russian speakers are (Golubeva et al. 2007).

Notwithstanding the tendency for Latvia's Russian-language press constantly to point out such discrimination, the data from the focus groups revealed a particular nuance of Russian speakers' existence in Latvia that has not been so evident in previous media analysis. In the Russian-language press the action of drawing attention to the discrimination of Russian speakers serves a useful 'othering' function: 'look how "they" treat "us!" However, for the focus group participants, when they talked of instances where they have felt excluded from certain of Latvia's social and political spheres, they did not necessarily link this with an attempt to depict the monstrous Latvian 'other'. Instead there was often simply sadness that at some level that they did not quite belong in Latvia:

I'm appalled by the words of my son, who, in a way, represents young people. He returns home and says 'Mum, at university in England, I talk with the guys from different European countries. They tell me about their homeland and I get the impression that they love their homeland'. And maybe he and others from Latvia miss certain things from home; they return home and 'Oh, this is where I used to play', 'This is where I went to pre-school'. But they don't have that feeling of homeland and they find that hard. (Respondent aged 40-60)

I think that Russians feel more at ease abroad than Latvians .... I'm saying this based on my friends and acquaintances, because this is our home country, but still it's not quite like that. The Latvian language and all the rest, and many people 
know Latvian, but still it's a little different. Latvians abroad miss Latvia. For them it's more of a homeland than for us. (Postgraduate respondent)

Of course, on one level it is rather sad to hear such sentiments. However, it is also encouraging that they were not accompanied by any vitriol directed towards Latvians or any other group. In fact, the respondents showed a great deal of empathy towards the position of Latvians - a phenomenon almost wholly absent from the pages of the Russian-language press:

Well, because in Riga it's roughly 50\% Russian and 50\% Latvian. You walk along the street and only hear Russian. It's not nice for Latvians which is why they make a fuss about it. Put yourself in their position - imagine I live in England and when I walk down the street there's only Latvians instead of people from England. Well, it wouldn't be nice. (Undergraduate respondent)

A very telling example of this empathy was displayed by one postgraduate who evidently had strong feelings on the issue of non-citizenship. However, even though he was able to convey his displeasure at this phenomenon, he was also at pains to bring attention to the plight of the 'Latvian nation' which he presumably felt went some way to explaining the current situation:

The thing is that we were born in the Soviet Union and ended up in Latvia. So the Union fell apart and we, kind of, it's kind of our homeland - I was born here but still we don't feel it.... Recently I saw a TV program where they were talking with our president Zalters, and for the Latvians, for the Latvian nation (latyshskii narod) it was much harder in the Soviet Union. He mentioned that they lived a double life.... I mean when they left their homes it was a Russian community, and they could only live a normal life at home, i.e. in Latvian.

But there's still this old, completely worn-out and tarnished thing - the fact that non-citizens don't have 'non-citizen' written in their passport, but 'alien'. (Postgraduate respondent)

Therefore there were cases where the focus group participants cited discrimination against them for being Russian speakers. Sometime this was more subtly expressed (as in the above quotation), sometimes it was more explicit. However, the anger expressed in the pages of the Russian-language press, or from Russian officials, was notably toned down. Instead, Russian speakers generally expressed a sense of miscomprehension rather than anger at certain phenomena, not least the status of 'non-citizens' for a large proportion of the population.

Certainly one potential reason why Russian speakers seem to be more phlegmatic in assessing their perceived discrimination in Latvia is that they are able to differentiate between interpersonal and intergroup relations. Studies have often found a link between positive interpersonal contacts across groups and improved intergroup relations. The most developed literature in this regard comes from social psychology and intergroup contact theory. In Pettigrew and Tropp's (2006) meta-analysis of 516 studies which employed such an approach, as many as 95\% reported a negative relationship between intergroup contact and prejudice. Additionally, friendships which transcend group boundaries have also been found negatively to correlate with 
prejudice (Hewstone et al. 2006; Van Dick et al. 2004). In the course of my focus group research the respondents indicated that they had a fairly high level of contact with Latvians either at work or in a social setting, and that they had little or no problems interacting with Latvians:

In my opinion it depends on the individual. So, like it or not, the general feeling between Russians and Latvians has formed like it has. However, when we're talking about an individual, when you take a concrete person, then in principle it's really easy, in my opinion, to talk with Latvians .... I have some acquaintances, not like super-good friends, just good acquaintances and we study together, relax, i.e. we all get on without any problems. There are jerks among Russians and among Latvians. (Postgraduate respondent)

Therefore, because of the relatively high level of contact between Russian speakers and Latvians, the respondents were able to openly acknowledge that the intergroup distance between Latvians and Russian speakers was most visible in the media and political spheres, and that in everyday life the two communities were far closer. In terms of interpersonal relations, Russian speakers were thus much more inclined to suggest that, on the whole, relations were not too bad (or at least not as bad as depicted in the media). This is a vitally important point to consider for our study. It would suggest that the distinctness of the two discursively proscribed communities seen within the country's media and politics is perhaps not as visible in the everyday interactions of Latvia's inhabitants.

However, even though the focus group respondents were more balanced in their opinions than journalists, a number of them nonetheless expressed their displeasure at the way Russian speakers were sometimes treated in Latvia. The most common gripe among the focus group participants was the issue of citizenship. For many people it would seem that the idea of non-citizenship is degrading and insulting. One man in the older age group joked that Russians were no longer lowly 'occupiers' in Latvia: 'Now Russians have lessened that to the grand status of... non-citizens! (Laughter)' (Respondent aged 40-60)'.

It would seem that the reason why the issue of non-citizenship is so offensive to Russian speakers is that it represents the most visible and actual sign that they have no legitimate place in Latvia. A discussion of the citizenship issue led one respondent to ask: 'Why do we always have to be second-class people?' (Respondent aged 40-60).

Moreover, there was a generally accepted notion that the Russian-speaking community, as a community, was indeed separate from the Latvian community. One undergraduate participant was particularly forceful in voicing their opinions. Asked whether the Russian-speaking community was very different from the Latvian community, they replied:

They are completely different. For example, I study at the University of Latvia and a majority of people there are Latvians, so in a way there is a lot of pressure on Russians. For example, if we don't know Latvian then we're somehow obliged to learn it. That's why since 1991, when Latvia became a separate state, there's been a war between Russians and Latvians. You know, it's complicated for Russians in Latvia. (Undergraduate respondent) 
Nevertheless, generally, the participants of the focus groups saw interpersonal relations in a relatively positive light. Indeed, while there was an abstract understanding that the two (imagined) communities were very separate, there was still a great deal of empathy, open-mindedness, and collectedness displayed by the respondents in the face of potentially very emotive issues. Perhaps one respondent summed up the general mood: 'There are only two nationalities: a good person and a bad person’ (Respondent aged 40-60).

\section{In Search of Homeland: Finding a Legitimate Place for Russian Speakers in Latvia}

Earlier I outlined the need to study Russian-speaking discourses within the framework of anti-, integrational, and constructive discursive strategies. In the Russian-language press constructive discourses have been increasingly employed as an important strategy to allow Russian speakers to preserve many discursive connections with their 'Russian' heritage and cultural belonging, while also acknowledging their loyalty and belonging to Latvia (Cheskin 2012). In the media discourse this was achieved by presenting Russian speakers as an economic, cultural, and political bridge between East (Russia) and West (Latvia/Europe). Certainly this was a strategy that was also evidenced in my focus group discussions. However, it was also accompanied by a counter-strategy - that of indicating that Russian speakers were neither Russian nor Latvian, and that they were a group of people stranded without a culture to call their own. On the one hand this could be perceived as a destructive, rather than constructive, discursive strategy. However, the discursive process of self-marginalization can also be seen as constructive, insomuch as it has potential to unite a group of people around the idea of marginalization and differentness. When asked if they considered Latvian culture part of their culture, a number of postgraduate students replied:

(Respondent 1) No. It's Latvian culture

(Respondent 2) As regards the culture of Latvia, we hardly, I mean, we don't try to penetrate it. It's there and that's fine.

(Respondent 1) Just like they don't penetrate [Russian culture].

(Respondent 2) It's not our [culture]. I mean from the outset we don't relate to Russia, although we relate to the Russian nation (narod). But we don't relate to Russia, and neither do we relate to Latvian culture. So that's the sort of community we have here. (Two postgraduate respondents)

This lack of belonging to either Russian or Latvian culture is linked to the sense that many of Latvia's Russian speakers seem to have of lacking a real homeland, or of not feeling completely accepted in Latvia as legitimate citizens. Nevertheless, although many Russian speakers may well feel at the margins of, or excluded completely from, Latvian culture, they still displayed a desire to maintain and cultivate links with both Russian and Latvian culture. 
It's best if you know Latvian and Russian. If you're a Russian, a Russian speaker, and you were born in Latvia, then it's desirable to know two cultures. (Postgraduate respondent)

I think that if there are Russians here then they shouldn't forget their own culture, and, how can I say this, well they should honor their traditions. But still they should know the Latvian language and shouldn't ignore it, like, I don't know, the majority of people over 40 who lived here in the Soviet Union who completely ignored it. (Undergraduate respondent)

If a family is planning on continuing to live here then I think that they simply need to know a bit about Latvian culture, some basic understandings, but also, of course about their own culture. And so when the question is asked 'What is your culture?' we can talk about 'our culture in Latvia'. (Postgraduate respondent)

The last two comments highlight the important point that younger Russian speakers want to be more integrated into Latvian culture than their parents. Here (as we have already seen) young Russian speakers are willing to acknowledge that Latvian language and culture were largely ignored during Soviet times, and wish to reverse that trend. Therefore there is evidence of a fairly strong desire to integrate into and learn Latvian culture. On the other hand, there is also a widespread and contradictory feeling that Latvian culture is 'Latvian', i.e. for 'Latvians' and not really their culture, which is compounded by the fact that Russian speakers often do not feel like Latvia is their genuine homeland. Further, there is an equally strong feeling that Russian speakers, while learning about Latvian culture, should not neglect their own Russian cultural heritage.

These three factors lead logically to the creation of a new discursive and symbolic position for Russian speakers in Latvia - the construction of a new identity which straddles both Russian and Latvian discourses, but which also creates a new identity; that of Russian speakers as a bridge between Russia and Europe. In the focus group discussions the respondents were presented with a quote from Chas (2010a) which championed the use of Russian as an economic resource for Latvia to build relations between the West and Russia. The respondents agreed entirely with this sentiment:

Because [language] is a resource. If you don't use a resource then someone else will use it.... But in principle Latvia has traditionally not utilized at all the resources which are here. So there's nothing surprising in this. (Postgraduate respondent)

As the conversation progressed from this quotation, one respondent agreed that Russian speakers were a bridge between Russia and Latvia: '[Russian speakers] are a bridge. All business relations are based on acquaintance, on family ties. All Russians work with Russia' (Respondent aged 40-60).

Admittedly, although the focus group participants were agreeable to the idea of Russian speakers functioning as a bridge between Russia and Latvia/Europe, they were not necessarily forthcoming in expressing this idea explicitly. Rather, the idea was somewhat elicited by me. In the above example, for example, I had asked outright if Russian speakers could be considered as a bridge between Russia and the West. 
Nevertheless, the idea still had resonance with the focus group participants. For most people it was desirable for Latvia to start to utilize its perceived geographical and linguistic advantages vis-à-vis Russia, and to put more efforts into developing economic ties with Russia:

It would be better for Latvia and relations with Russia would be much better. That would be ideal.

Latvia would have contact with Europe and would be a bridge to Russia. Yes, and in terms of geography it's also in a good position. (Two undergraduate respondents in response to the question 'What do you think of the idea that Russian speakers in Latvia can become a bridge between the West and Russia? Have you heard of this idea?’)

It was also significant that almost the exact same sentiment was similarly expressed by the postgraduate group of respondents:

Yes, the geographical position [is advantageous] - I mean Latvia as a bridge from Europe to Russia, i.e. through Latvia, i.e. talking about freight, connections, and logistics - in that respect. (Postgraduate respondent in response to the question 'Would you say that Latvia was in an advantageous geographical position?')

Thus, in the first example from the undergraduate group, the prompt of a bridge between the West and Russia elicited an explanation that Latvia was in an advantageous geographical position. In the second example the prompt was the advantageous geographical position and the elicited response was that Latvia was a bridge between Europe and Russia.

However, in terms of national identity, Russian speakers seemed to be more concerned with 'concrete' issues such as economics and social cohesion rather than ethnicity or language:

For people now, well, in our country in our situation it's important to solve all these economic problems. Language is already, I don't know, it's an anachronism. (Undergraduate respondent)

For this reason the bridge between Russia and Europe is perceived less as a symbolic device which gives meaning and legitimacy to Russian speakers in Latvia, and more as a pragmatic approach to dealing with Latvia's largest neighbor. This was largely confirmed by the respondents' reaction to another excerpt from Chas (2010b) where it was claimed that 'the so-called ethnic problems' were no longer so important for Latvia's inhabitants, as economic concerns were far more important. The majority of participants agreed:

(Respondent 1) We're used to it now.

(Respondent 2) We're used to it and we know the [Latvian] language.

(Respondent 1) About five or six years ago [ethnic issues] were very salient. It all happened when there were these [education] reforms.

(Respondent 3) Yes, and we even played an active role in them. 
(Respondent 2) Yes, we did then, but now we've become accustomed to it, we've got used to it, and we've come to terms with it. Well, what can you do? It's just the way it is. But Latvians (latyshi) are also such a phlegmatic nation. (Three postgraduate respondents)

It would thus appear that Russian speakers in Latvia are starting to come to terms with their government's policies on education and citizenship. This potentially allows them to integrate much deeper into 'Latvian' discourses. Moreover, although Russian speakers do not necessarily see the bridge function as an explicit component of their identity, the idea nevertheless still seems to hold great appeal to them.

This pragmatic approach to ethnic relations within Latvia must therefore be understood as a useful means for Russian speakers to find their place in contemporary Latvia. There would seem to be a realization that the state policies on language, education, and citizenship are hardly likely to change. As such, Russian speakers are increasingly learning to accept them. Indeed, we may posit that the more 'ethnic issues' are removed from the political agenda, the less Russian speakers will feel estranged from all things 'Latvian'. To this end, a pragmatic and stoical approach to ethnic relations, with an increasing focus on the economic and social issues which affect all of Latvia's inhabitants equally, holds much potential for Russian speakers.

This can be seen in the new optimism of Russian speakers. The discourse of self-marginalization, which has traditionally been a staple of Russian-language media discourse since Latvia regained independence in 1991 (Golubeva et al. 2007), stresses how hard it is to be a Russian speaker in Latvia. However, within media discourse, Russian speakers are increasingly pointing to their advantageous position in Latvia. This was also reflected in our discussions:

(Respondent) Well, if you take any job advertisement, then it will have requirements for Latvian, Russian, and English, for example. So Russian is always there now and employers want to have Russian workers, which means they won't pay full attention to whether or not you speak Latvian.

(Interviewer) So, in terms of economics, in Latvia it's better to be Russian?

(Respondent) Yes. (Undergraduate respondent)

In response to the question of whether it was difficult to be a Russian in Latvia, the group of postgraduate respondents immediately pointed out that it was, in fact, more difficult for Latvians in many respects:

It will probably be more difficult for Latvians.

Because of this policy which has been carried out...then with their Latvian language, in principle, there's nowhere for them to go except for Latvia. Those who've learned English are lucky, but many haven't even learned English. If Russians can at least reorient themselves towards Russia, then Latvians can't. (Two postgraduate students)

This optimism with regard to the economic standing of Russian speakers stood in contrast to the resignation and concern the respondents expressed regarding their 
difficulty finding symbolic acceptance and belonging in Latvia. Indeed, one thing that this optimism does enable is the partial disavowal of the self-marginalization strategy that has been identified within Russian-speaking discourse. The idea that Russian speakers are able to forge their own future instead of being held back by discrimination appeared to be an empowering concept. This was demonstrated when the focus group participants were shown an excerpt from Chas, in which the author railed against the people who have introduced Latvian language requirements for most professions. In the article the author, somewhat dramatically, links these language requirements with eventual homelessness: 'What follows is simple: no language, no job; no job, no income. That means poverty which means the street' (Chas 2009). However, as one postgraduate participant responded:

I would say that here it's actually pretty debatable. Firstly, because if you look where it was published - in the newspaper Chas, which is a radical enough Russian newspaper. Secondly, it also seems a little far-fetched that for twenty years Russians have been screaming that we haven't been given any opportunities. If it was 1995 , then it would be understandable, but this is 2011, and 21 years have now passed. And it's worth saying that Latvians are forcing us to learn, but we forget that in this time Russians could have already leant Latvian. And for the many people who haven't in this time period, in actual fact, it's their problem. I would say that because for pupils, students, and everyone else it's no longer an inherent problem. (Postgraduate student)

\section{Conclusions}

My interviews with Russian speakers in Latvia allow us to observe some of the nuances of identity formation which are missed by analyses of media and political discourses in isolation. By comparing previous media analysis of Russian-speaking discourse with the data from these focus groups it is clear that while there may be a fair amount of overlap between the positions of the media and prominent political 'representatives' of the Russian community, there is nevertheless also a great deal of divergence. This was demonstrated in the respondents' response to a number of the newspaper excerpts that were presented in the course of the focus groups.

The main object of this study was to determine how Russian speakers were, or were not, able to integrate various (often competing) discursive positions into their sense of identity. Certainly, by studying contemporary discourses in relation to previously established nodal points we can see that young Russian speakers are increasingly able to adopt certain 'Latvian' discourses and narratives, and to integrate them alongside certain 'Russian' ones.

Of course, we need to bear in mind that the younger respondents of these focus groups were well educated, and therefore more likely to have learned Latvian well. A group of similarly aged Russian speakers outside university may well have led to very different conclusions. Nevertheless, it is significant that a group of Russian 
speakers have been able to adapt themselves to the realities of their Latvian environment, and that they have increasingly been able to see themselves as distinct from Russians in Russia, while also tentatively moving towards Latvian culture and discursive understandings.

Overall then there is much to be optimistic about concerning Russian speakers' ability to integrate their own sense of identity into the prevailing and institutionalized discourses associated with the Latvian state. Proponents of Latvia's harsh citizenship laws and language policies may see this as justification for these policies. On the face of it Russian speakers seem to be more able to integrate themselves into Latvian discourses and the generational evolution in attitudes would point to the continuation of this process in the future. However, one of the reasons Russian speakers have been able to better integrate themselves in Latvian state discourses is that they have found a way to simultaneously hold onto a number of discursive and identity poles which mark them as culturally Russian.

Russian speakers, it would seem, are unable to integrate fully into Latvian discourses because they still feel that Latvian culture is not their culture. This is therefore something that state legislators should bear in mind when, for example, debating whether to move from having $60 \%$ of school teaching in Latvian to $100 \%$, or of the need to reduce the amount of Russian-language media in Latvia. To attempt to remove the influence of Russian culture and various aspects of Russian identity would surely only lead to a return of discourses of marginalization and discrimination. Instead, policy makers should focus on making Latvian culture more accessible for Russian speakers, while also coming to terms with (and even embracing) the fact that Russian speakers increasingly see themselves as members of the Russian cultural world (russkii mir) but not the Russian political world (rossiskii mir). For young Russian speakers in Latvia the ideal identity appears to be no more exclusively Latvian than exclusively Russian. Instead, this research indicates that there is great potential for an integrated, yet culturally distinct, Latvian-Russian identity.

\section{Notes}

1 I have tidied up the English translation used in the Baltic Times and also put the words vobla, vodka, and Chastushki back into their original Russian in the way that President Vīkse-Freiberga used them.

2 In Russia sunflower seeds are a popular snack, often sold by street vendors. The reference here is to the shells of the seeds, which are often spat out or thrown away onto the street - a practice often seen as uncouth.

3 This quotation was analyzed as part of my media analysis of Russian-speaking discourse in Cheskin 2012, p. 336

4 For a good discussion of the functions of the Baltic states' 'occupation museums' see Velmet 2011. To be fair to Latvia's Occupation Museum, Velmet sees that the museum (in contrast to the Museum of the Occupations in Tallinn) also acknowledges its problematic role as an identity constructor.

5 The words 'non-citizen' and 'alien' were used here in English. 


\section{References}

Aasland, A. (1994) 'The Russian Population in Latvia: An Integrated Minority?', Journal of Communist Studies and Transition Politics, 10, 2, pp 233-60.

Aasland, A. (2002) 'Citizenship Status and Social Exclusion in Estonia and Latvia', Journal of Baltic Studies, 3, 1, pp. 57-77.

Baltic Times (2010) 'Russia's Trojan horses: The spy-cons denounce the ways of Russian influence', 20 October.

Bell, D. (2008) 'Agonistic Democracy and the Politics of Memory', Constellations, 15, 1, pp. $148-66$.

Berg, E. \& Ehin, P. (eds) (2009) Identity and Foreign Policy: Baltic-Russian Relations and European Integration (Farnham, Ashgate).

Brubaker, R. (1992) 'Citizenship Struggles in Soviet Successor States', International Migration Review, 26, 2, pp. 269-91.

Brubaker, R. (1996) Nationalism Reframed: Nationhood and the National Question in the New Europe (Cambridge, Cambridge University Press).

Chas (2008) 'Konstantin Kosachev: "Ne davat' Rodinu v obidu”, 11 December.

Chas (2009) 'Kto krainii v ocheredi za yazykom?', 26 February.

Chas (2010a) 'Russkomu - ofitsial'nyi status' 20 September.

Chas (2010b) '... i uleteli "pchely", 6 October.

Cheskin, A. (2010) 'The Discursive Construction of "Russian-Speakers": The RussianLanguage Media and Demarcated Political Identities in Latvia', in Golubeva, M. \& Gould, R. (eds) Shrinking Citizenship: Discursive Practices that Limit Democratic Participation in Latvian Politics (Amsterdam, Rodopi), pp. 133-54.

Cheskin, A. (2012) 'Synthesis and Conflict: Russian-Speakers' Discursive Response to Latvia's Nationalizing State', Europe-Asia Studies, 64, 2, pp. 325-47.

Chinn, J. \& Truex, L. (1996) 'The Question of Citizenship in the Baltics', Journal of Democracy, 7, 1, pp. 133-47.

Croucher, S. (2004) Globalization and Belonging: The Politics of Identity in a Changing World (Lanham, Rowman \& Littlefield).

De Cilia, R., Reisigl, M. \& Wodak, R. (1999) 'The Discursive Construction of National Identities', Discourse \& Society, 10, 4, pp. 149-73.

Eglitis, D. (2002) Imagining the Nation History, Modernity, and Revolution in Latvia (Pennsylvania, Pennsylvania State University Press).

Foreign Policy Concept of the Russian Federation (2008), available at: http:// archive.kremlin.ru/eng/text/docs/2008/07/204750.shtml, last accessed 16 June 2011.

Galbreath, D. (2006) 'European Integration Through Democratic Conditionality: Latvia in the Context of Minority Rights', Journal of Contemporary European Studies, 14, 1, pp. 69-87.

Golubeva, M. (2011) 'Different History, Different Citizenship? Competing Narratives and Diverging Civil Enculturation in Majority and Minority Schools in Estonia and Latvia', Journal of Baltic Studies, 41, 3, pp. 315-29.

Golubeva, M. \& Kažoka, I. (2010) 'Moral Superiority and the Soviet Stigma: Parliamentary Speech and Attribution of Blame in Political Discourse', in Golubeva, M. \& Gould, R. (eds) Shrinking Citizenship: Discursive Practices that Limit Democratic Participation in Latvian Politics (Amsterdam, Rodopi), pp. 171-94. 
Golubeva, M., Rožukalne, A. \& Kažoka, I. (2007) Izaicinājums pilsoniskajai līdzdalībai: Analītiskais ziņojums par Saeimas un mediju monitoring (Riga, Sabiedriskās politikas centrs Providus).

Hall, S. (1980) 'Encoding/Decoding', in Durham, M. \& Kellner, D. (eds) Media and Cultural Studies: Keyworks (Malden, Blackwell), pp. 166-76.

Hewstone, M., Cairns, E., Voci, A., Hamberger, J. \& Niens, U. (2006) 'Intergroup Contact, Forgiveness, and Experience of "The Troubles" in Northern Ireland', Journal of Social Issues, 62, 1, pp. 99-120.

Hogan-Brun, G. (2006) 'At the Interface of Language Ideology and Practice: The Public Discourse Surrounding the 2004 Education Reform in Latvia', Language Policy, 5, pp. 313-33.

Kattago, S. (2010) 'Memory, Pluralism and the Agony of Politics', Journal of Baltic Studies, 41, 3, pp. 383-94.

Kažoka, I. (2010) 'Latvian Political Party System and the Discourse on Parties', in Golubeva, M. \& Gould, R. (eds) in Shrinking Citizenship: Discursive Practices that Limit Democratic Participation in Latvian Politics (Amsterdam, Rodopi), pp. 67-80.

Laitin, D. (1995) 'Identity in Formation: The Russian-Speaking Nationality in the PostSoviet Diaspora', European Journal of Sociology, 36, 2, pp. 281-316.

Laitin, D. (1998) Identity in Formation: The Russian-Speaking Populations in the Near Abroad (London, Cornell University Press).

Laitin, D. (2003) 'Three Models of Integration and the Estonian/Russian Reality', Journal of Baltic Studies, 34, 2, pp. 197-222.

Makarov, V. \& Boldāne, I. (2008) 20. gadsimta vēstures pretrunīgo jautājumu pasniegšana. Latvijas skolās un muzejos (Riga, Sorosa Fonds Latvija), available at: http:// www.politika.lv/index, accessed 02 June 2011.

Mälksoo, M. (2009) 'Liminality and Contested Europeanness: Conflicting Memory Politics in the Baltic Space', in Berg, E. \& Ehin, P. (eds) Identity and Foreign Policy: Baltic-Russian Relations and European Integration (Farnham, Ashgate), pp. 65-83.

Melvin, N. (1995) Russians Beyond Russia: The Politics of National Identity (London, Royal Institute of International Affairs).

Mikkel, E. \& Pridham, G. (2005) "Clinching the "return to Europe": the referendums on EU accession in Latvia and Estonia', in Szczerbiak, A. \& Taggart, P. (eds) EU Enlargement and Referendums (Abingdon, Routledge), pp. 160-92.

Muižnieks, N. (2011) Latvian-Russian Relations: Dynamics Since Latvia’s Accession to the EU and NATO (Riga, University of Latvia Press).

Onken, E. (2007) 'The Baltic States and Moscow's 9 May Commemoration: Analyzing Memory Politics in Europe', Europe-Asia Studies, 59, 1, pp. 23-46.

Peschel, K. (1998) 'Perspectives of Regional Development Around the Baltic Sea', The Annuls of Regional Science, 32, pp. 299-320.

Pettigrew, T. \& Tropp, L. (2006) 'A Meta-Analytic Test of Intergroup Contact Theory', Journal of Personality and Social Psychology, 90, 5, pp. 751-83.

Pisarenko, O. (2006) 'The Acculturation Modes of Russian-Speaking Adolescents in Latvia: Perceived Discrimination and Knowledge of the Latvian Language', EuropeAsia Studies, 58, 5, pp. 571-73.

Priedīte, A. (2005) 'Surveying Language Attitudes and Practices in Latvia', Journal of Multilingual and Multicultural Development, 26, 5, pp. 409-24.

Rodins, M. (2005) 'National Identity and Democratic Integration in Latvia in the Middle of the 90s', Latvijas Universitātes Raksti, 686, pp. 40-63. 
Rožukalne, A. (2010) 'Latvian Print Media as Opinion Leaders', in Golubeva, M. \& Gould, R. (eds) Shrinking Citizenship: Discursive Practices that Limit Democratic Participation in Latvian Politics (Amsterdam, Rodopi), pp. 67-80.

Smith, G. (1999) The Post-Soviet States: Mapping the Politics of Transition (London, Arnold). Smith, G., Law, V., Wilson, A., Bohr, A. \& Allworth, E. (1998) Nation-Building in the PostSoviet Borderlands: The Politics of National Identities (Cambridge, Cambridge University Press).

Solska, M. (2011) 'Citizenship, Collective Identity and the International Impact on Integration Policy in Estonia, Latvia and Lithuania', Europe-Asia Studies, 63, 6, pp. 1089-108.

Šulmane, I. \& Kruks, S. (2001) 'Stereotipi Latvijas presē', Latvijas mediju analīze (Riga, Daudzveidība III), pp. 11-50.

Tabuns, A. (1999) Changing National, State and Regime Identities in Latvia, Open Society Institute, available at: http://rss.archives.ceu.hu/archive/00001156/01/168.pdf, accessed 13 December 2011.

Van Dick, R., Wagner, U., Pettigrew, T., Christ, O., Wolf, C., Petzel, T., et al. (2004) 'The Role of Perceived Importance in Intergroup Contact', Journal of Personality and Social Psychology, 87, 2, pp. 211-227.

Velmet, A. (2011) 'Occupied Identities: National Narratives in Baltic Museums of Occupations', Journal of Baltic Studies, 42, 2, pp. 189-211.

Vihalemm, T. \& Masso, A. (2003) 'Identity Dynamics of Russian-Speakers of Estonia in the Transition Period', Journal of Baltic Studies, 34, 1, pp. 92-116.

Zepa, B. (2006) The Changing Discourse of Minority Identities (Riga, Baltic Institute for Social Sciences), available at: http://pdc.ceu.hu/archive/00002159/01/Brigita_ident_ Engl.pdf, accessed 13 June 2011.

Zepa, B., Sūpule, I., Kļave, E., Krastiņa, L., Krišāne, J. \& Tomsone, I. (2005) Etnopolitiskā spriedze Latvijā: Konflikta risinājuma meklējumi (Riga, Baltic Institute for Social Sciences), available at: http://www.bszi.lv/downloads/resources/Etnopol_krize/ Atskaite_LV.pdf, accessed 16/June 2011.

Zepa, B., Šūpule, I., Krastiņa, L., Ķešāne, I., Grīviņš, M., Bebriša, I. \& Ieviņa, I. 2006) Integration Practice and Perspectives (Baltic Institute of Social Sciences), available at: http://www.bszi.lv/downloads/resources/integracijas_prakse/brosura_EN. pdf, accessed 13 December 2011.

Zepa, B., Žabko, O. \& Vaivode, L. (2008) Language (Baltic Institute of Social Sciences), available at: http://www.bszi.lv/downloads/resources/valoda/valoda2008_en.pdf, accessed 13 December 2011.

Ammon Cheskin is a lecturer in Nationalism and Identity at the University of Glasgow in the School of Social and Political Sciences. He was awarded a CRCEES studentship to complete a PhD and an MRes in Russian, Central and East European Studies at the University of Glasgow. He also holds an MA in Russian Interpreting and Translation and a BA in Russian and Politics from the University of Bath. (ammoncheskin@yahoo.com). 